\title{
Chromium supplementation modulates glucose metabolism in heat- stressed Girolando dairy cows
}

\section{Suplementação com cromo modula o metabolismo de glicose de vacas Girolando sob estresse térmico pelo calor}

\author{
Lilian dos Santos Ribeiro ${ }^{1 *}$; Felipe Zandonadi Brandão²; Luciano de Rezende \\ Carvalheira ${ }^{3}$; Diana Rangel de Lemos ${ }^{4}$; Gustavo Torres de Souza ${ }^{5}$; Ribrio Ivan Tavares \\ Pereira Batista ${ }^{6}$; Luiz Sérgio de Almeida Camargo ${ }^{7}$; Bruno Campos de Carvalho ${ }^{7}$
}

\begin{abstract}
Highlights:
Heat-stressed, chromium-supplemented cows had low GLUT2, G6Pase, and rGH mRNA abundance. In thermoneutral conditions, chromium-supplemented cows had low IGF1 expression. Heat-stressed cows fed a control diet had high GLUT2 mRNA abundance.
\end{abstract}

\begin{abstract}
The objective of this study was to evaluate the effects of dietary chromium supplementation on hepatic gene expression of lactating Girolando (Holstein x Gyr) cows under heat stress conditions in climatic chamber. Thirty-six $3 / 4$ Holstein $x$ Gyr lactating cows were used, based on a $2 \times 3$ factorial scheme, to evaluate the effects of two diets $\left(0 \mathrm{vs} 0.50 \mathrm{mg}\right.$ of organic chromium $\mathrm{kg}^{-1}$ dry matter) and three environmental conditions (ECs): heat stress conditions in climatic chamber with ad libitum feeding (HS), a thermoneutral environment with ad libitum feeding (TN), and a pair-fed group in a thermoneutral environment (PF). Under HS group, the expression levels of glucose transporter 2 (GLUT2), glucose-6-phosphatase (G6Pase), and growth hormone receptor (rGH) were downregulated $(P<0.05)$ in chromium-supplemented cows compared to those in cows fed the control diet. GLUT2 expression was upregulated $(P=0.02)$ in the HS group and insulin-like growth factor 1 (IGF1) was downregulated $(P<0.01)$ in the PF group in cows fed the control diet compared to the expression in the TN group. No differences were observed between the ECs in terms of relative abundances of GLUT2, phosphoenolpyruvate carboxykinase (PEPCK), G6Pase, rGH, and IGF1 transcripts among the chromium-supplemented cows $(P>0.05)$. Heat stress caused changes in the expression of genes related to glucose metabolism, and organic chromium could modulate glucose metabolism in animals under heat stress conditions to some extent.
\end{abstract}

Key words: Crossbred cows. Dairy cattle. Glucose metabolism. Liver biopsy.

\footnotetext{
1 Discente do Curso de Doutorado do Programa de Pós-Graduação em Medicina Veterinária, Faculdade de Veterinária, Universidade Federal Fluminense, UFF, Niterói, RJ, Brasil. E-mail: lilianribeiro91@hotmail.com

2 Prof. Dr., UFF, Niterói, RJ, Brasil. E-mail: fzbrandao@id.uff.br

3 Discente do Curso de Doutorado do Programa de Pós-Graduação em Ciência Animal, Escola de Veterinária, Universidade Federal de Minas Gerais, UFMG, Belo Horizonte, MG, Brasil. E-mail: 1rcarvalheira@gmail.com

4 Discente do Curso de Mestrado do Programa de Pós-Graduação em Medicina Veterinária, Departamento de Veterinária, Universidade Federal de Viçosa, UFV, Viçosa, MG, Brasil. E-mail: dianalemosvet@gmail.com

5 Discente do Curso de Doutorado do Programa de Pós-Graduação em Ciências Biológicas, Instituto de Ciências Biológicas, Universidade Federal de Juiz de Fora, UFJF, Juiz de Fora, MG, Brasil. E-mail: gustavotsouza@hotmail.com

6 Pesquisador de Pós-Doutorado do Programa de Pós-Graduação em Medicina Veterinária, UFF, Niterói, RJ, Brasil. E-mail: ribrio@yahoo.com.br

7 Pesquisadores, Empresa Brasileira de Pesquisa Agropecuária, EMBRAPA Gado de Leite, Juiz de Fora, MG, Brasil. E-mail: luiz. camargo@embrapa.br; bruno.carvalho@embrapa.br

Author for correspondence
} 


\section{Resumo}

O objetivo deste estudo foi avaliar o efeito da suplementação com cromo na dieta na expressão gênica hepática de vacas Girolando (Holstein x Gyr) sob estresse térmico pelo calor em câmara climática. Foram utilizadas 36 vacas da raça Holandês x Gir, em um esquema fatorial 2x3, para avaliar duas dietas ( 0 vs $0,50 \mathrm{mg}$ de cromo orgânico $\mathrm{kg}^{-1}$ de matéria seca) e três condições ambientais: condições de estresse térmico pelo calor em câmara climática com alimentação ad libitum (HS), ambiente termoneutro com alimentação ad libitum (TN) e um grupo com alimentação restrita em um ambiente termoneutro (PF). No grupo HS, as expressões de transportador de glicose 2 (GLUT2), glicose-6-fosfatase (G6Pase) e receptor de hormônio de crescimento $(\mathrm{rGH})$ foram reguladas negativamente $(P<0,05)$ nas vacas suplementadas com cromo orgânico em comparação com as vacas alimentadas com a dieta controle. A expressão de GLUT2 foi regulada positivamente $(P<0,02)$ no grupo HS e o fator de crescimento semelhante à insulina 1 (IGF1) foi regulado negativamente $(P<0,01)$ no grupo PF em comparação com o grupo TN para as vacas alimentadas com a dieta controle. Não foram observadas diferenças entre as diferentes condições ambientais na abundância relativa de GLUT2, fosfoenolpiruvato carboxiquinase (PEPCK), G6Pase, rGH e transcritos de IGF1 para as vacas suplementadas com cromo orgânico $(P>0.05)$. O estresse térmico pelo calor causou alterações na expressão de genes relacionados ao metabolismo da glicose, e o cromo orgânico pode modular o metabolismo da glicose em animais sob essas condições de estresse pelo calor.

Palavras-chave: Vacas mestiças. Gado de leite. Metabolismo de glicose. Biopsia de fígado.

Dairy herds in tropical countries are often comprised of crossbred Bos primigenius taurus $\mathrm{x}$ Bos primigenius indicus cows in order to take advantage of heterosis and the characteristics of zebu breeds, such as resistance to heat (Camargo et al., 2007). Girolando cows (Holstein x Gyr) are the most commonly-used breed for milk production in Brazil, combining the productivity of the Holstein breed with the rusticity of the Gyr breed. Under heat stress, cows usually reduce their dry matter intake and exhibit higher insulin plasma concentrations, despite lower glucose concentrations (Wheelock, Rhoads, Van Baale, Sanders, \& Baumgard, 2010; Baumgard et al., 2011). In an evaluation of cows subjected to heat stress and cows subjected to restricted feeding, it was observed that the reduction in consumption was only responsible for about 35 $\%$ of the observed reduction in milk production (M. L. Rhoads et al., 2010). This suggests that the ambient temperature affects milk production through mechanisms independent of reduction nutrient consumption (Baumgard et al., 2011). Even when cows under heat stress reduce their dry matter intake, they do not mobilize adipose tissue because insulin is an anti-lipolytic hormone (Wheelock et al., 2010). Therefore, there seems to be a change in post-absorptive metabolism even though the cows are in a negative energy state (R. P. Rhoads, Baumgard, Suagee, \& Sanders, 2013). Changes in glucose metabolism involve the liver, thereby altering fundamental metabolic pathways such as gluconeogenesis (Baumgard et al., 2011).

Chromium is a mineral that acts as an insulin cofactor and increases cell efficiency in capturing glucose. Chromium is responsive to plasma insulin concentration; it forms a complex with apochromodulin, which is activated and, in turn, binds to the active site of the insulin receptor, completing the activation of the receptor and amplifying the insulin signal (Pechova \& Pavlata, 2007). Thus, chromium supplementation may modulate glucose hepatic metabolism in heatstressed animals due to its role in amplifying the insulin signal in cells and in subsequent events. The objective of this study was to evaluate the effects of dietary organic chromium supplementation on the expression profiles of genes related to the hepatic metabolism of glucose in lactating Girolando cows subjected to heat stress. 
The present study was conducted at the José Henrique Bruschi experimental field of Embrapa Gado de Leite, located in Coronel Pacheco, Minas Gerais, Brazil. The study has been approved by the Comitê de Ética em Uso de Animais of Embrapa Gado de Leite (Protocol 07/2015) and follows the ethical principles of the National Council for Animal Experimentation Control. Thirty-six $3 / 4$ Holstein x Gyr cows that averaged $71.3 \pm 15.3$ days in milk, $509 \pm 61$ $\mathrm{kg}$ in body weight, body condition scores of $3.5 \pm 0.2$ (Edmonson, Lean, Weaver, Farver, \& Webster, 1989) at the beginning of the trial, $21.4 \pm 3.6 \mathrm{~kg}$ in milk production, and $19.2 \pm 2.4 \mathrm{~kg}$ in dry matter intake were used in the trial. The diet was based on corn silage, ground corn, soybean meal, and a mineral mixture supplemented (or not) with chromium tripicolinate (TecNutri, Montes Claros, Brazil) offered in a total mixed ration (42\% dry matter and $12.39 \% \mathrm{CP}$, $33.44 \% \mathrm{NDF}, 0.57 \% \mathrm{Ca}, 0.46 \% \mathrm{P}$ and $1.71 \mathrm{Mcal}$ $\mathrm{kg}^{-1}$ net energy based on dry matter), according to the nutritional requirements for cows producing $25 \mathrm{~kg}$ of milk day ${ }^{-1}$ National Research Council [NRC, 2001]; water was provided ad libitum.

After a seven-day adaptation period to the installations, the cows were randomly allocated to the two diet groups in which the two diets, namely control and organic chromium supplementation $(0.50 \mathrm{mg} \mathrm{Cr}$ $\mathrm{kg}^{-1}$ dry matter) (Sadri et al., 2009), were offered ad libitum in a thermoneutral environment for 25 days. Subsequently, the cows were divided into three environmental condition (EC) groups: heat stress in a climatic chamber with a temperature and humidity index (THI) of 85 with an eight-hour gap between milkings and ad libitum feeding (HS); a thermoneutral environment with a THI of 68 in a free stall fed ad libitum $(\mathrm{TN})$; and a pair-fed group in a thermoneutral environment with a THI of 68 in a free stall (PF). Thus, the effect of chromium supplementation under three environmental conditions could be evaluated, totaling six contemporaneous groups comprising six animals each. The climatic chamber could hold six animals, which were kept in individual stalls with access to the diet and water ad libitum. The chamber was set to THI 85, with a temperature of $34{ }^{\circ} \mathrm{C}$ and $60 \%$ humidity. The HS group was maintained under these conditions for 11 days of the trial. The diet offered to the PF cows was adjusted daily according to the intake of the heat-stressed cows on the previous day. The PF group was used to isolate the effect of DMI reduction in heat-stressed animals. As the capacity of climatic chamber is only hold six animals at a time, the trial was conducted in two phases with 18 animals per phase to achieve the necessary number of repetitions.

Hepatic tissue samples were collected through blind percutaneous needle biopsies (Tru-Cut semiautomatic biopsy needle, ProMedical, Juiz de Fora, Minas Gerais, Brazil) under local anesthesia with 5 $\mathrm{mL}$ of $2 \%$ lidocaine, at a point corresponding to the topographic position of the right lobe of the liver. Tissues were packed into microtubes (free of RNAse and DNAse) with $100 \mu \mathrm{L}$ of RNA Later (Ambion $\left.{ }^{\circledR}\right)$, according to the manufacturer's recommendations. Samples were kept refrigerated overnight, after which the excess RNA Later was drained and samples were stored in a freezer at $-80^{\circ} \mathrm{C}$.

Glucose transporter 2 (GLUT2), phosphoenolpyruvate carboxykinase (PEPCK), glucose-6-phosphatase (G6Pase), growth hormone receptor $(\mathrm{rGH})$ and transcripts of insulin-like growth factor 1 (IGF1) were used as calibrators to compare metabolic status across treatments as they are indicators of the abundance of mRNA encoding hepatic glucose metabolism. Total RNA was extracted using TRIzol ${ }^{\mathrm{TM}}$ Reagent (Invitrogen) at a rate of $1 \mathrm{~mL}$ per $100 \mathrm{mg}$ of tissue. Tissues were ground (tissue + TRIzol $^{\mathrm{TM}}$ Reagent) with $\mathrm{T} 10$ basic ULTRA-TURRAX ${ }^{\circledR}$ (IKA) until complete dissociation. Subsequently, $100 \mu \mathrm{L}$ of chloroform was added and the mixture was homogenized and incubated for three minutes. The samples were then centrifuged for 15 minutes at $12000 \mathrm{rpm} / 4{ }^{\circ} \mathrm{C}$. The liquid phase was collected and transferred to a clean tube, after which $500 \mu \mathrm{L}$ isopropanol was added to each tube to be incubated for 10 minutes. Samples were homogenized by inversion and were then 
centrifuged for 10 minutes at $12000 \mathrm{rpm} / 4{ }^{\circ} \mathrm{C}$. The supernatant was discarded, and the precipitate was washed in $1 \mathrm{~mL}$ of $75 \%$ ethanol. The material was centrifuged again at $7500 \mathrm{rpm}$ for five minutes, and the supernatant was discarded. The pellet was dried for five minutes and was then suspended in $50 \mu 1$ RNasefree ultrapure water. The total RNA concentration was measured using a ND-100 spectrophotometer (NanoDrop Products). The integrity of the RNA was evaluated by agarose gel electrophoresis.

Afterwards, reverse transcription was performed using Superscript III kits (Invitrogen), according to the manufacturer's recommendations. Relative quantification by real-time qPCR was performed in triplicate using a commercially available SYBR green. Reactions $(20 \mu \mathrm{L})$ were prepared according to the manufacturer's instructions using SYBR green kits (Power Up SYBR Green; Invitrogen), 3.3 ng cDNA, nuclease-free water, and specific primers for each reaction. Primers for the following genes were designed: GLUT2 (accession number: NM_001103222.1; forward: 5'-ACAAGCCTGGGAGATCCAAC-3'; reverse: 5'-CCCAAGCAACCCTCCAAAGA-3'; annealing temperature: $54.0^{\circ} \mathrm{C}$ ), PEPCK (accession number: NM_174737.2; forward: 5'-CAAGGATGGGGAGCCTTGTG-3'; reverse: 5 ' - C C T C G TA G A C C A G A G G G A C A - 3'; annealing temperature: $55.0^{\circ} \mathrm{C}$ ), G6Pase (accession number: NM_001076124.2; forward: 5 ' - AT G T T G T GG T T G G G AT T C T G G - 3'; reverse: 5'-CACCTTCGCTTGGCTTTCTC-3'; annealing temperature: $52.0^{\circ} \mathrm{C}$ ), $\mathrm{rGH}$ (accession number: NM_176608.1; forward: 5'-GGTATGGATCTCTGGCAGCTG-3'; reverse: 5'-CTCTGACAAGGAAAGCTGGTGTG-3'; annealing temperature: $\left.55.0^{\circ} \mathrm{C}\right), \quad \mathrm{IGF} 1$ (accession number: NM_001077828.1; forward: 5'-TTGGTGGATGCTCTCCAGTTC-3'; reverse: 5'-GCACTCATCCACGATTCCTGT-3'; annealing temperature: $54.0^{\circ} \mathrm{C}$ ), glyceraldehyde-3-phosphate dehydrogenase(GAPDH; accessionnumber:U85042; forward: 5'-GTCTTCACTACCATGGAGAAGG-3'; reverse: 5'-TCATGGATGACCTTGGCCAG-3'; annealing temperature: $51.0^{\circ} \mathrm{C}$ ), and tyrosine 3-monooxygenase/tryptophan 5-monooxygenase activation protein zeta (YWHAZ; accession number: $\quad$ NM_174814.2; forward: 5'-GCAAAAGACGGAAGGTGCTG-3'; reverse: 5'-CCTCAGCCAAGTAGCGGTA-3'; annealing temperature: $52.0^{\circ} \mathrm{C}$ ).

The template cDNA was denatured at $95{ }^{\circ} \mathrm{C}$ for 15 seconds for 40 cycles, at the gene-specific primer annealing temperature for 15 seconds, and for elongation at $72{ }^{\circ} \mathrm{C}$ for one minute. After each PCR run, a melting curve analysis was performed to confirm that a single specific product was generated. No-template controls (NTCs), comprising the PCR reaction mix without a DNA template, were also run with each primer to confirm the absence of contamination. Green fluorescence data were acquired during the extension step. The expression of each target gene was normalized using the geometric mean of the values obtained for glyceraldehyde-3phosphate dehydrogenase (GAPDH) and tyrosine 3-monooxygenase/tryptophan 5-monooxygenase activation protein zeta (YWHAZ) transcripts (endogenous genes).

The efficiencies of the primers were tested using Lin-RegPCR software (Ramakers, Ruijter, Deprez, \& Moorman, 2003) for each reaction. Relative quantification of differential expression (QR) was performed using REST software (Pfaffl, Horgan, \& Dempfle, 2002) using the comparative threshold cycle method (Livak \& Schimittgen, 2001) (QR $\left.={ }^{2-\Delta \Delta C t}\right)$. To evaluate each expression level, one calibrator group was used as a comparison. Thus, the data obtained were expressed as ' $\mathrm{N}$ times' relative to the calibrator group; $P<0.05$ was considered the level of significance.

Under HS, the levels of GLUT2, G6Pase, and rGH were downregulated $(0.44 \pm 0.42,0.46 \pm$ 0.43 and $0.32 \pm 0.27$, respectively, $P<0.05$ ) in chromium-supplemented cows compared to the levels in cows fed the control diet (Figure 1). Under 
TN treatment, IGF1 expression was downregulated $(0.09 \pm 0.07 ; P<0.01)$ in chromium-supplemented cows compared to that in cows fed the control diet. GLUT2 expression was upregulated (2.94 $\pm 3.78 ; P$ $=0.02)$ in the HS group compared to that in the TN group in cows fed the control diet. The expression of rGH was downregulated $(0.24 \pm 0.22 ; P=0.02)$ in the PF group compared to that in heat-stressed cows, and IGF1 was downregulated $(0.10 \pm 0.09$; $P<0.01)$ in the PF group compared to that in the TN group in cows fed the control diet (Figure 2A). However, no differences were observed in the relative abundances of GLUT2, PEPCK, G6Pase, rGH, and IGF1 transcripts among the different ECs in the chromium-supplemented cows $(P>0.05$; Figure 2B).

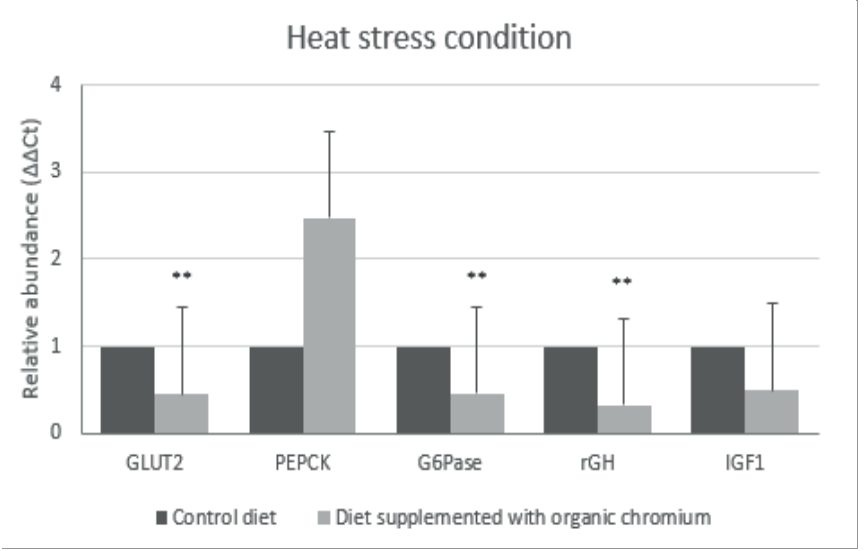

Figure 1. Relative expression levels of GLUT2, PEPCK, G6Pase, rGH, and IGF1 in the hepatic tissues of lactating Girolando cows under heat stress conditions in a climatic chamber. $(* *)$ downregulated $(P<0.05)$. GLUT2: glucose transporter 2; PEPCK: phosphoenolpyruvate carboxykinase; G6Pase: glucose 6-phosphatase; rGH: growth hormone receptor; IGF1: insulin-like growth factor 1.

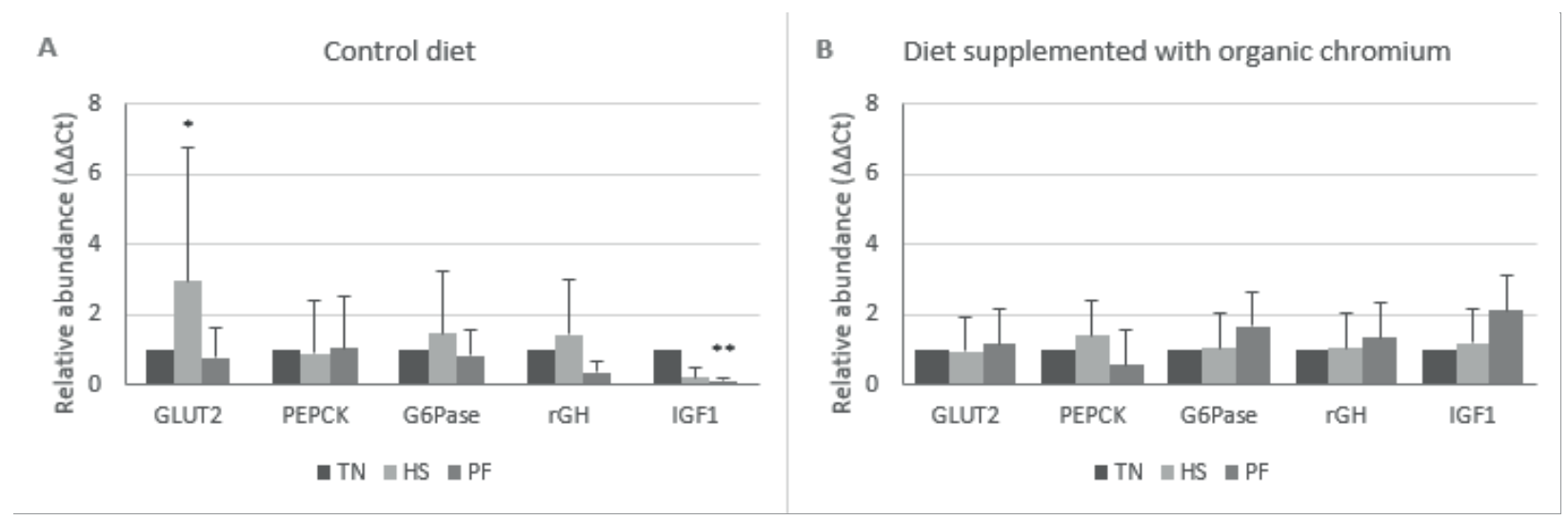

Figure 2. Relative expression levels of GLUT2, PEPCK, G6Pase, rGH, and IGF1 in the hepatic tissues of lactating Girolando cows fed, A: A control diet. B: A diet supplemented with organic chromium (0.50 mg Cr kg-1 dry matter). (*) upregulated; $(* *)$ downregulated $(P<0.05)$. GLUT2: glucose transporter 2; PEPCK: phosphoenolpyruvate carboxykinase; G6Pase: glucose 6-phosphatase; rGH: growth hormone receptor; IGF1: insulin-like growth factor 1. $\mathrm{TN}$ : thermoneutral environment with feeding ad libitum; HS: heat stress conditions in a climatic chamber with feeding ad libitum; PF: pair-fed group in a thermoneutral environment. 
Increasing selection pressure for milk production leads to increased metabolic heat being produced by cows during lactation, which aggravates heat stress in tropical regions. This illustrates the need to develop alternative strategies, potentially targeting metabolic adaptations designed to alleviate the negative effects of heat stress on dairy cattle production (Wheelock et al., 2010).

Cows under heat stress have higher peripheral glucose metabolism. This metabolic alteration signals a strategy of greater heat dissipation in the peripheral tissues. However, changes in glucose metabolism are not restricted to the peripheral tissues as they involve the liver (Baumgard et al., 2011), which is the primary site of glucose production in ruminants (Collier, Collier, Rhoads, \& Baumgard, 2008). Thus, fundamental metabolic pathways are altered (R. P. Rhoads, La Noce, Wheelock, \& Baumgard, 2011). Ruminants obtain a small part of their glucose directly from the diet, and rely on gluconeogenesis as a fundamental method of supplying extra-hepatic tissues with glucose. Under heat stress conditions, the cows exhibit lower plasma concentrations of growth hormone (GH), subregulation of rGH, and less IGF1 gene expression. IGF1 produced in the liver under GH stimulation is important for milk synthesis in dairy cattle, and GH stimulates lipid mobilization and inhibits the action of insulin. Hence, lower GH concentrations favor increased insulin concentrations (M. L. Rhoads et al., 2010). Insulin is an anti-lipolytic hormone, thus, it limits the energy supply and initiates processes that provide glucose to the body, such as glycogenolysis and gluconeogenesis (R. P. Rhoads et al., 2011).

The expression profiles of enzymes essential for gluconeogenesis change during a heat stress period in a manner that is apparently dependent on the nutritional plane (R. P. Rhoads et al., 2011). The abundance of PEPCK, an enzyme involved in the gluconeogenesis metabolic pathway, increased during feed restriction but was not affected by heat stress. The increased hepatic glucose output also originates from increased glycogenolysis. Glucose- 6-phosphate is converted to glucose during the final steps of gluconeogenesis and glycogenolysis. This conversion, catalyzed by G6Pase, is an essential step in glucose homeostasis and only glucose, not glucose-6-phosphate, can leave the liver and enter the bloodstream, a process mediated by GLUT2 (Hah, Ryu, Lee, Jung, \& Lachaal, 2002).

Under heat stress conditions, the abundances of GLUT2, G6Pase, and rGH mRNA were decreased in chromium-supplemented cows compared to those in cows fed the control diet. Increasing the plasma insulin concentration results in chromium moving from the plasma to insulin-dependent cells. Four $\mathrm{Cr}^{3+}$ ions join apochromodulin (without $\mathrm{Cr}^{3+}$ ), activating it as chromodulin, which binds to the active site on the insulin receptor, completing its activation and amplifying the insulin signal (Pechova \& Pavlata, 2007). The binding of insulin to its transmembrane receptor causes a conformational change which stimulates the translocation of glucose transporters to the plasma membrane. With the increase in efficiency of glucose uptake by cells caused by the organic chromium, supplemented cows have less of a need to activate gluconeogenesis and glycogenolysis pathways for glucose supply, which explains the lower G6Pase and GLUT2 mRNA abundances. Although they exhibited reduced rGH, the supplemented cows did not differ from nonsupplemented cows in IGF1 mRNA abundance. Thus, IGF1 production via GH stimulation in the liver was not affected.

Under heat stress conditions, the increased insulin concentration (M. L. Rhoads et al., 2010), and anti-lipolytic action of insulin, stimulates the initiating the processes of generating glucose in the body, such as glycogenolysis and gluconeogenesis, and GLUT2 mediates the process of transporting glucose from the liver to the bloodstream. IGF1 mRNA abundance was downregulated in the PF group compared to that in the TN group in cows fed the control diet. Undernutrition affects the plasma concentration of IGF 1 and can attenuate the IGF1 response to $\mathrm{GH}$ as well as affect the regulation of 
IGF1 normally ascribed to GH (Zulu, Nakao, \& Sawamukai, 2002). The absence of changes in the mRNA expression of the studied genes in chromiumsupplemented cows under different environmental conditions indicates that organic chromium affects glucose metabolism, or at least that it regulates the studied genes related to glucose metabolism at the mRNA level.

In conclusion, heat stress caused changes in the expression levels of genes related to glucose metabolism, and organic chromium was able to modulate glucose metabolism through the potentiation of insulin action in animals under heat stress conditions to some extent.

\section{Acknowledgments}

The authors thank the Universidade Federal Fluminense, Embrapa Gado de Leite, Fundação de Amparo à Pesquisa de Minas Gerais (FAPEMIG) and Fundação de Amparo à Pesquisa do Estado do Rio de Janeiro (FAPERJ). This study was financed in part by the Coordenação de Aperfeiçoamento de Pessoal de Nível Superior-Brasil (CAPES) Finance Code 001.

\section{References}

Baumgard, L. H., Wheelock, J. B., Sanders, S. R., Moore, C. E., Green, H. B., Waldron, M. R., \& Rhoads, R. P. (2011). Postabsorptive carbohydrate adaptations to heat stress and monensin supplementation in lactating Holstein cows. Journal of Dairy Science, 94(11), 5620-5633. doi: 10.3168/jds.2011-4462

Camargo, L. S. A., Viana, J. H. M., Ramos, A. A., Serapião, R. V., Sa, F. de, Ferreira, A. M., Guimarães, M. F. M., \& Vale, V. R. do, Fo . (2007). Developmental competence and expression of the Hsp 70.1 gene in oocytes obtained from Bos indicus and Bos taurus dairy cows in a tropical environment. Theriogenology, 68(4), 626-632. doi: 10.1016/j. theriogenology.2007.03.029

Collier, R. J., Collier, J. L., Rhoads, R. P., \& Baumgard, L. H. (2008). Genes involved in the bovine heat stress response. Journal of Dairy Science, 91(2), 445-454. doi: $10.3168 /$ jds.2007-0540
Edmonson, A. J., Lean, I. J., Weaver, L. D., Farver, T., \& Webster, G. (1989). Body condition scoring chart of Holstein dairy cows. Journal of Dairy Science, 72(1), 68-78. doi: 10.3168/jds.S0022-0302(89)79081-0

Hah, S. J., Ryu, J., Lee, W., Jung, C. Y., \& Lachaal, M. (2002). The hepatocyte glucose-6-phosphatase subcomponent T3: Its relationship to GLUT2. Biochimica et Biophysica, 1564(1), 198-206. doi: 10. 1016/S0005-2736(02)00450-9

Livak, K. J., \& Schmittgen, T. D. (2001). Analysis of relative gene expression data using real time quantitative PCR and the $2 \Delta \Delta \mathrm{C}(\mathrm{T})$. Method. Methods, 25(4), 402-408. doi: 10.1006/meth.2001.1262

National Research Council 2001. Nutrient Requirements of Dairy Cattle: Seventh Revised Edition, 2001. Washington, DC: The National Academies Press. doi: $10.17226 / 9825$

Pechova, A., \& Pavlata, L. (2007). Chromium as an essential nutrient: a review. Veterinary Medicine (Praha), 52(1), 1-18. doi: 10.17221/2010-VETMED

Pfaffl, M. W., Horgan, G. W., \& Dempfle, L. (2002). Relative Expression Software Tool $\left(\mathrm{REST}^{\odot}\right)$ for group wise comparison and statistical analysis of relative expression results in real-time PCR. Nucleic Acids Research, 30(9), e36. doi: 10.1093/ nar/30.9.e36

Ramakers, C., Ruijter, J. M., Deprez, R. H., \& Moorman, A. F. M. (2003). Assumption-free analysis of quantitative real-time polymerase chain reaction (PCR) data. Neuroscience Letters, 339(1), 62-66. doi: 10.1016/S0304-3940(02)01423-4

Rhoads, M. L., Kim, J. W., Collier, R. J., Crooker, B. A., Boisclair, Y. R., Baumgard, L. H., \& Rhoads, R. P. (2010). Effect of heat stress and nutrition on lactating Holstein cows: II. Aspects of hepatic growth hormone responsiveness. Journal of Dairy Science, 93(1), 170-179. doi: 10.3168/jds.2009-246

Rhoads, R. P., Baumgard, L. H., Suagee, J. K., \& Sanders, S. R. (2013). Nutritional interventions to alleviate the negative consequences of heat stress. Advances in Nutrition, 4(3), 267-276. doi: 10.3945/an.112. 003376

Rhoads, R. P., La Noce, A. J., Wheelock, J. B., \& Baumgard, L. H. (2011). Short communication: alterations in expression of gluconeogenic genes during heat stress and exogenous bovine somatotropin administration. Journal of Dairy Science, 94(4), 1917-1921. doi: 10.3168/jds.2010-3722 
Sadri, H., Ghorbani, G. R., Rahmani, H. R., Samie, A. H., Khorvash, M., \& Bruckmaier, R. M. (2009). Chromium supplementation and substitution of barley grain with corn: Effects on performance and lactation in periparturient dairy cows. Journal of Dairy Science, 92(11), 5411-5418. doi: 10.3168/jds. 2008-1877

Wheelock, J. B., Rhoads, R. P., Van Baale, M. J., Sanders, S. R., \& Baumgard, L. H. (2010). Effects of heat stress on energetic metabolism in lactating Holstein cows. Journal of Dairy Science, 93(2), 644-655. doi: 10.3168/jds.2009-2295
Zulu, V. C., Nakao, T., \& Sawamukai, Y. (2002). Insulinlike growth factor- I as a possible hormonal mediator of nutritional regulation of reproduction in cattle. Journal of Veterinary Medical Science, 64(8), 657665. doi: 10.1292/jvms.64.657 